\title{
近世水運における中小河川の舟溜り 仙台付近の例
}

\author{
若 生 達 夫（宮城教育大学）
}

地理教育と歴史教育とを結ぶ教材例として，舟溜り や荷揚げ場の位置・造りを，合流の型・潮汐現象との 関係で述べる。17 世紀以降の仙台周辺に見られる事例 を示すが，その中のあるものは現在に継承され，災害 にかかわっているとの観点も示したい。

\section{1. 合流の型を意図した荷揚げ場 一一広瀬川・木流} 堀

木流堀は，仙台城下への燃料材輸送のため, 名取川 から広瀬川に向けて作られた水路である(索引図)。こ の堀の流未つまり広瀬川に入る直前で, 郡山堀を分け る(図 1a)。木流堀の少なくとも一部は藩政時代以前に すでに存在しており, 郡山堀は古代（多賀国府以前の 郡山遺跡に官衙・寺院のあった頃）にすでに引かれて いた可能性がある(若生，1992)。ここでは，木流堀流 末付近のことに絞る。

用水路は，普通，汎用的ないし多目的的である。水 田用であっても，農民とそれ以外の人久の生活用水。 消火用水でもあり, また, 季節に応じて主用途が交替 する。木流堀は, 実は, 農業用の幹線用水路であり,木 流しは，冬・早春だけ行われた(明治初頭まで続く。郷 土史案内板, 武山(1935)その他による)。

ここで話題としたいのは，木流堀流末が，広瀬川の 川上に向って逆向き鋭角に進むこと，また，その合流 点手前で南に流れる郡山堀を分ける, そのパターンに ついてである（図 1a)。

[木流堀流末］図 $1 \mathrm{~b}$ は，仙台市が下水道計画のた めに土地の起伏を詳細に測量した地図の一部である。 水路名の記入は無い。後述の藩政時代絵図により, 御 流木蔵のあった地点を示した。

この図では，A， B , Cの 3 本の細長い窪地が見られ，

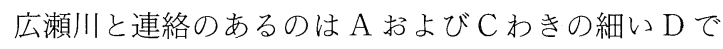
ある。藩政時代の 3 時期の絵図（高倉ほか，1994）は, 城下町を主として描いていて，この流末付近の詳細は 無いが, 次の点は読みとれる。また郡山堀の取水口の
位置について武山(1935)の記述が参考になる。 これらをならべてみると：

1691 ・92 年 (元禄 4 ・5) の図—A・B・Cに水色の 水路表示。

1786 89 年(天明 6 寛政元) の図一同上。 1844〜48 年(弘化年間) の大洪水の後,「河床が低下し て引水不能となり—」, 郡山堀取水口が変更され た。C・D 地点付近にあたるか。

1856〜 59 年(安政 3〜6) の図—A のみ。

郡山堀が木流堀流未付近から分枝。

1893 年(明治 26 ) の図 (図 $1 \mathrm{~b}) \longrightarrow \mathrm{A} \cdot \mathrm{B} \cdot \mathrm{C}$ の細長い

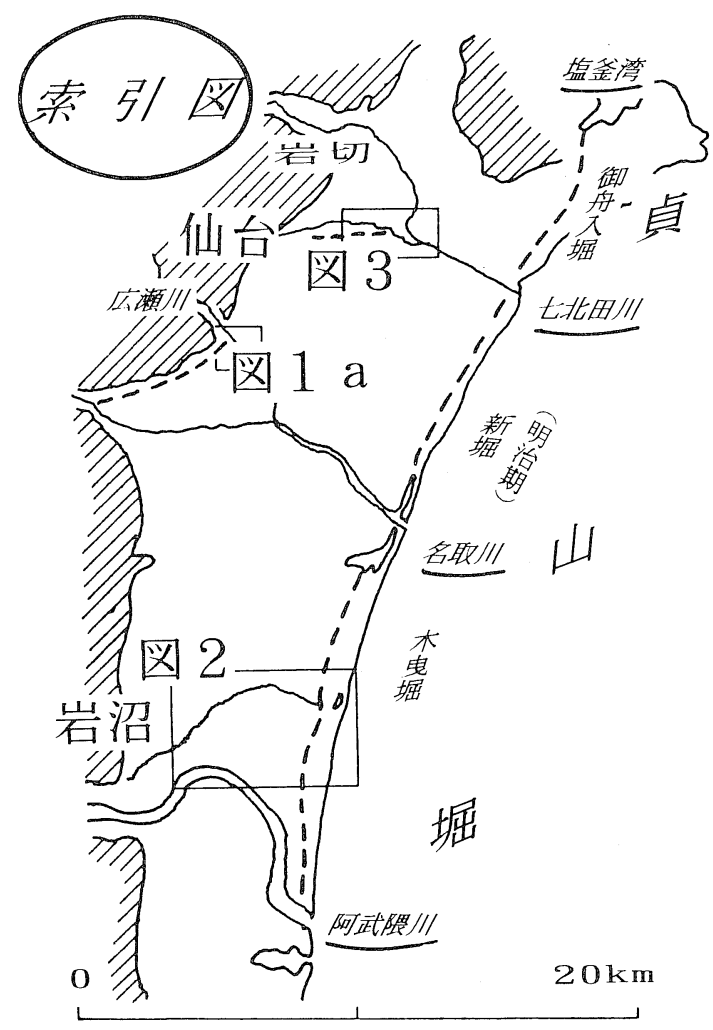



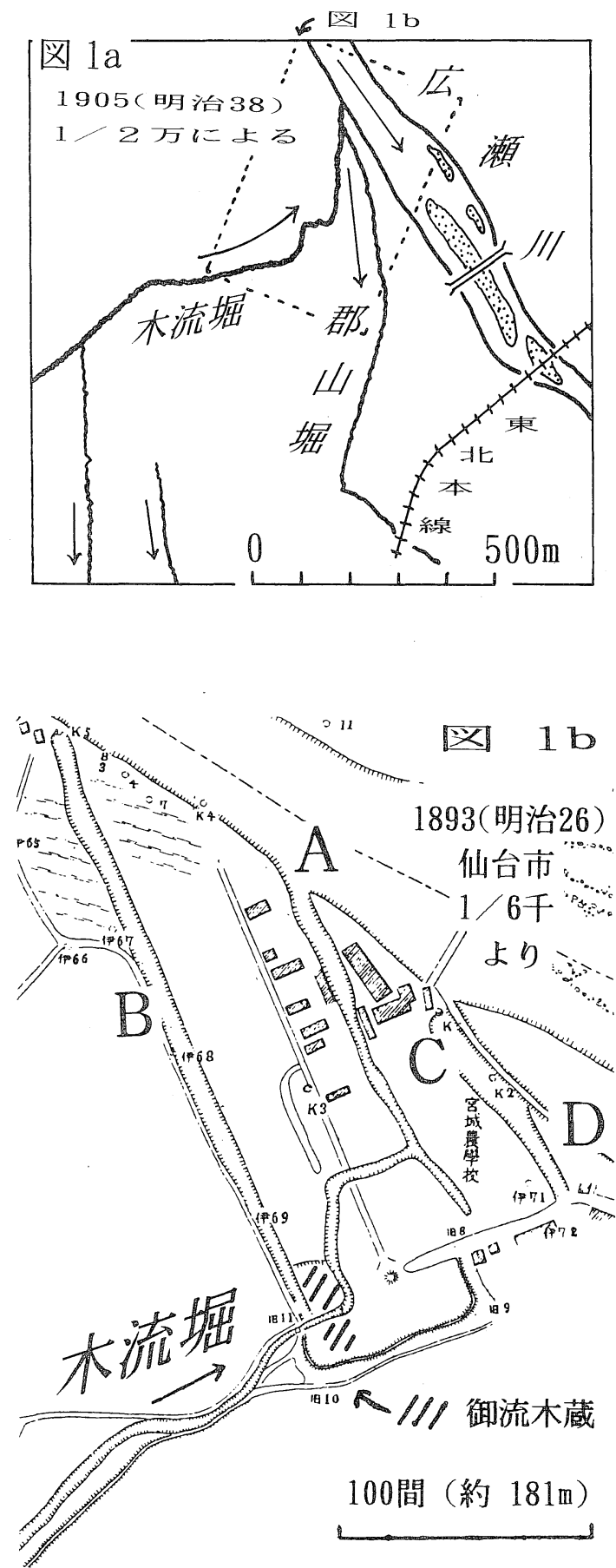

窪地が見られ，A と D が広瀬川に連絡。 1905 年(明治 38) の図（図 1a)—A のみ。広瀬川に 連絡する木流堀から，郡山堀が分枝。

なお，明治中期図の D が郡山堀だとすると，話がや やこしくなるが, 明治中期には，郡山堀の取水口が安 政図より前の状態に戻され，明治後期に再び安政図の 形になって現在に引き継がれたと解釈する他はない。

話を木流堀流未にもどす。図 $1 \mathrm{~b}$ の窪地 $\mathrm{B} ・ \mathrm{C}$ は，こ の当時に存在した $\mathrm{A}$ と共に, 広瀬川の側の河道変化な ぞに対応しながら，その流末を広瀬川の川上に向けて 逆向き鋭角で進ませる。そんな執念・意図があったこ とを示唆する。すなわち, 流末には広瀬川の水が入り こみ, 停滞水域ができて, 流されてきた燃料材の広瀬 川への流亡防止と荷揚げを容易にする，そんなメカ二 ズムのための設計であったろう。

普通, 河川防災には Y 字型の合流, 時には背(瀬)割 堤による合流点の下流への移動が行われる（木曽三川 や宮城県の鳴瀬川・吉田川。武田信玄の甲府盆地は, 盆 地尻では同様。中程では，釜無川に対する支流御勅使 (みだい)川の合流点の上流への移動で直角的流入が計 られたが，これは例外的な「水をもって水を制する」思 想・方策で，孫子の兵法に学んだものとされている (甲 府盆地の地誌や河川土木の書物による)。

木流堀流末のこの例をみると, 治水にしろ利水にし ろ，たまたま兵法と結びつけられて解説される例があ るにしても，時代や土地柄に応じた技術あるいは生活 の知恵があったと思われる。渡来人の知識を含む弥生 時代以降の水に関する技術に照らせば，この推定には 無理がないと考える。むしろ，科学的数值計算や学問 に慣らされている現代人には気づきにくい, 弱点と 言ってもいいような事例ではなかろうか。

[郡山堀との関係］すでに述べたように，郡山堀の 取水地点は，広瀬川からであったり木流堀流末からで あったり, 年代的変化・先祖返り的変化があったよう である。この堀は, 現在, 農業用水路であるが, 汎用 性の高かった昔は勿論, 今でさえ管理用水という名で, 稲作期以外でも通水するのである。従って，木流しの 行なわれた冬・早春と稲作期とでは水量の違いこそあ れ, 広瀬川か木流堀から，この郡山堀に通水されてい た筈である。

木流堀と関わっていた時には, 季節的に, 水門の操 
作によって，両水路のそれぞれの汎用性を維持したと 思われる。

[現況］木流堀は, 1980 年頃に都市排水専用の水路 に転換され，流未はやや直角で広瀬川に入る。農業用 幹線水路の役割は, 補償工事により暗渠でなされてい る。郡山堀は,より上流側に広瀬川を横断する取水堰 が設置されており，木流堀とはサイホン(伏越)で立体 交差している。

\section{2. 潮汐利用の舟溜り——岩沼ふきん五間堀川}

仙台空港の南にあるこの川に，畜産業者が污物を垂 れ流ししたとして，1993 年に書類送検された。この川 は感潮河川であり, 干満に応じて污物は行ったり来た りしたであろう。旧版地形図には, 図 2 に 箇所に，汐入川記号が書かれていた。

仙台南方の砂浜海岸には河口閉塞された小河川が多 く(阿武隈川・名取川のような大きな川も閉塞気味で ある),それによって生じた沼地などを連結して浜堤内 側に運河が作られてきた。図 2 の中の木曳(こびき)堀 は，伊達政宗時代に阿武隈川・名取川それぞれの河口 付近を結び(索引図), 仙台城近くの広瀬川に大橋を作 るための木材が運搬されたという記録もある。政宗の 後, 塩釜湾と七北田川とを結ぶ御舟入堀も開削され, 明 治になってこれら 2 つ堀をつなぐ水路が作られて， 塩釜湾〜阿武隈川河口付近を結ぶ動脈が完成した。貞 山公政宗にちなみ, 貞山運河 (別称, 貞山堀) と名付け られた。大正時代に，塩釜東方に産する野蒜(のびる) 石が、この運河を使って運ばれたなど，いろいろ知ら

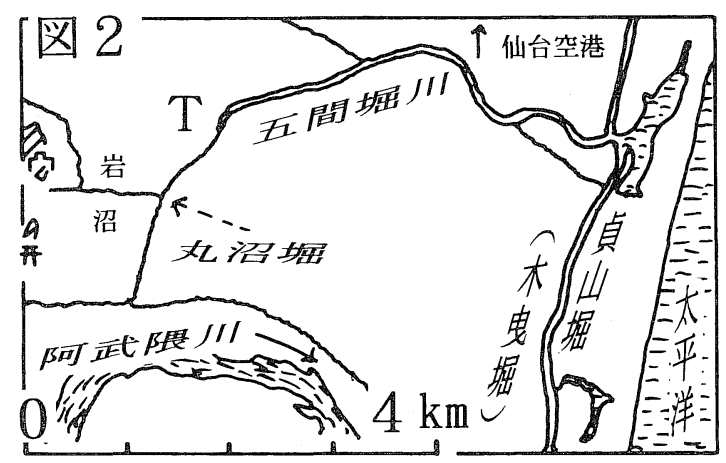

1907 (日月治 40) 1/2万による
れている。

図 2 の T と記した地点までは貞山堀との間の五間 堀川の川幅は広く，ここに倉庫があった。昭和の初ま で，ここが荷の積み替え地点であり，貞山堀を通じて くる満潮時の上げ潮を利用したことは，現況から推定 して誤りではない。中世の岩沼館の時代には, 丸沼堀 のそばに職人町があり，昭和の初には，その水運によ る「やおや市」がたっていた（若生，1991）。

[現況］ 1980 年前後, 名取川の頭首工(農業用・上水 道用・工業用の取水堰) の改築という利水工事と並行し て, この付近一帯の排水改良工事が進められた。前記 の木流堀もその一つであり，この五間堀川・丸沼堀も 拡幅など排水機能強化の工事がなされた。

1986 年 8 月初めの台風で, 仙台空港(海抜約 $2 \mathrm{~m}$ )を 含む岩沼東方低地(同約 $90 \mathrm{~cm}$ の所もある) の内水汇 濫(湛水・冠水)が発生した。海岸付近の浜堤と阿武郎 川などの丈夫な堤防の存在の結果である。七夕豪雨と 言われたこの雨台風は，仙台での観測が 8 月 4.5 日に $416 \mathrm{~mm}$ を記録した(平年の年間降水量は約 1,200 $\mathrm{mm})$ 。東北地方建設局・宮城県の災害記録にはないこ となのだが，この両日は，旧暦 6 月 29・30日，つまり， 旧暦 7 月 1 日(朔，新月)の大潮をむかえる時期であっ た。この付近では, 大潮の満潮時に $50 \sim 60 \mathrm{~cm}$ の水位 上昇がある。過去・現在の利水・治水をみる時, 地理 分野からこの種の事項への注目喚起も行うべきであろ う。

1994 年, 東北地建・県は, 五間堀川から阿武隈川 の排水路 2 本, 海岸付近に遊水地 1 つ, および排水ポ ンプ場 3 つの建設計画を発表した（朝日新聞，1994.7. 28)。

実は, 貞山堀は, 運輸に加え排水機能を負わされて おり,この運河沿いには多数の排水ポンプ場がある。河 口閉塞の河川の肩代わりである。閉塞で生じた沼など を連結して作られた,ということと董腹の関係になる。 一方, 名取川・阿武隈川などを通じて干満を内陸に伝 える道にもなっていて, 数行前に “この種の事項” と曖 昧に書いたメリットとデメリットとでも言おうか, そ んな両面をもっている。さらに一方，阿武隅川最下流 部は，洪水流を早く・確実に海に排水するという高水 工事の論理の下にあり，七夕豪雨でも破堤はなく，ま たそのため，岩沼付近低地にたまった水は出て行く所 
がなかった。

今回の建設計画は, 並の洪水時の排水は貞山堀に出 すにしても, 阿武隈川最下流部もその沿岸の排水の受 け皿にするという画期的な考えの変更であろう。

\section{3. 合流の型と潮汐の組み合わせを意図した舟溜り —七北田川・梅田川}

七北田川の下流部，岩切から河口までの 12〜13 km は,藩政時代に放水路として開削されたと言われる(例 えば東北土木学会，1969，p. 338）。既存分流路の利用 か全く新規開削かなど解明されていない事があるが， この下流部に, 次の特徵がある (索引図) : (1)ここに述 べる梅田川との合流点を境として，上流は曲流し下流 は直線流路である。(2) 七北田川のこの工事の 15 年後 に始まった塩釜湾から七北田川河口付近への貞山堀は 御舟入堀と呼ばれている。したがって，七北田川下流 部は, 河口閉塞に対する放水路というだけではなく,水 運をも含めたこの付近の水路システムの開発と受け 取った方がよい。実際, 関連して舟曳堀も掘られ, 西 の方の城下に近い所まで米・塩などが運ばれた（国道 45 号線は, 舟曳き道 towpath を兼社た道路の発展し たものである)（若生，1990）。

図 3 は,この七北田川に西の方から梅田川が合流し, この合流点付近に舟曳堀の東端が置かれたことを示 す。すなわち，御舟入堀・七北田川で上がってきた物 資は，梅田川流末で降ろされ舟曳堀の小舟に積み替え られたのである。
梅田川の合流のしかたは，Y 字型ではなく，円弧状 に遠回りでなされる。その分，勾配は小さくなった筈 である。しかも, 図は不鮮明であるが, 合流点の七北 田川に汐入川記号 (2 本の平行な反対向きの矢印) があ る。実際, 満潮時に現地を見ると, 七北田川の上げ潮 と梅田川流末の停滞が見られる。土地の人は, 七北田 川が逆流し梅田川は止められると言って, 見慣れた光 景のようである。

この停滞状態は, 上げ潮に乗って上り, 停滞水域に 入って荷揚げすることを意図して計画的に作られたも のではなかろうか。別な表現で繰り返せば，ここから 下流が直線流路の七北田川の治水・利水の効果の反面, 梅田川の排水効率が落とされることを意味する。

［現況］主題でないので具体的記述は省略するが, 梅田川の下流部は，古くから，農業用水・雨水などの 排水の役割を担っていた(取水はされていない)。周囲 は, 長く水田地带であった。しかし, 地方中心都市の 周辺地域の例にもれず, 今は宅地化されている。2で述 べた 1986.8 七夕豪雨で, この付近でも内水氾濫はひど かった。梅田川の流路は藩政時代のまま，合流点のす ぐ下流の七北田川に向けて, 巨大な鶴巻排水機場が設 置された（図 3 )。

干満差 5 6 m のドーバー海峡・テムズ川（若生, 1993）もこの小論のヒントになっている。水運に関し て地方史・経済史から書かれることが多いのは国の内 外で共通することのようであるが,ここに示した例は, 過去の事象の解釈だけでなく, 土地の特性を象徵する

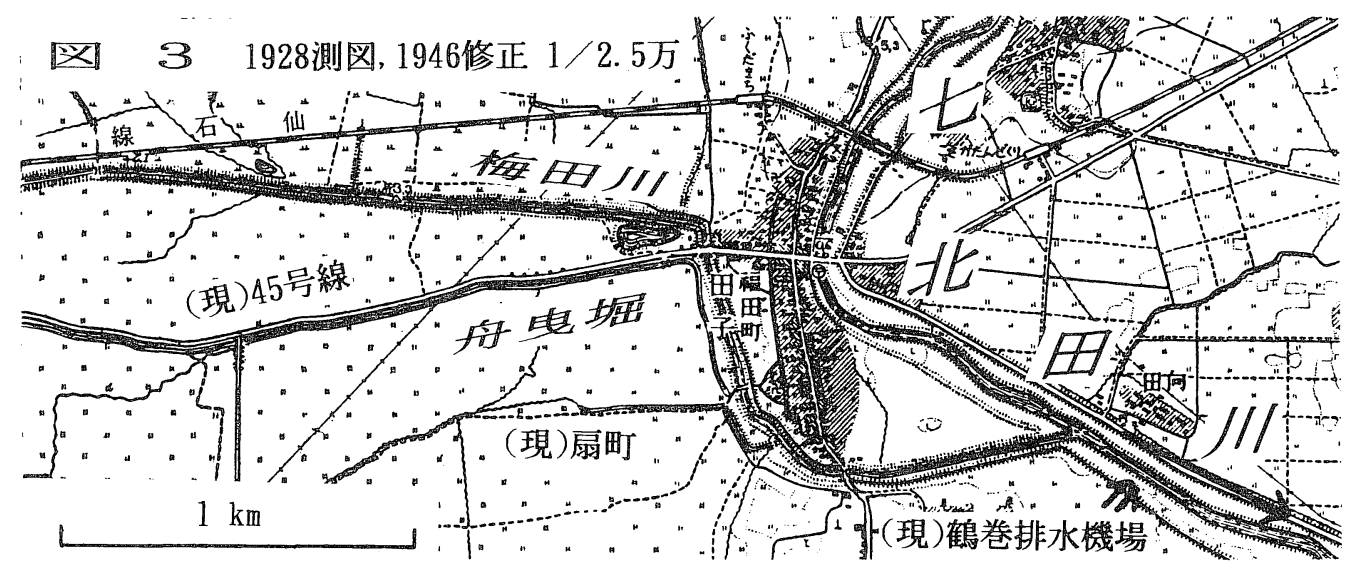

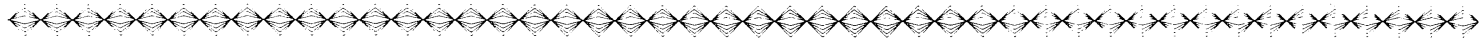


ものであって，地理学徒が現代の諸問題に対する場合 の視点の取り方のひとつにならないだろうか。

文献

高倉 淳ほか編 (1994): 絵図・地図で見る仙台. 今野 印刷，仙台，折図 11 葉・説明パンフレット

武山豊治（1935）：仙台市の郷土地誌的概観 (15)。仙台 郷土研究，5，170-180.

東北土木学会 (1969): 東北の土木史. 同学会, 仙台, 476 頁。

若生達夫 (1990)：地理教育雑録 6. 河川の地理（その
3: 広瀬川の中流の例で). 宮教大紀要, 25, 145159 .

若生達夫 (1991)：地理教育雑録 7。水路の自然地理 (その 1 : 岩沼, 五間堀川の例で). 宮教大紀要, 26, 25-36.

若生達夫 (1992)：地理教育雑録 8. 水路の自然地理 (その 2 : 歴史的継承性を含めて)。宮教大紀要, 27, 55-64.

若生達夫（1993）：地理教育雑録 9.ロンドンの自然地 理（その 1 : ロンドン港)。宮教大紀要， 28,129 145.

\section{The Make-up of Landing Position for Water-carriage} around Sendai during the Shogunate Era

Tatsuo WAKŌ, Miyagi University of Education 